\title{
Postoperative junctional ectopic tachycardia
}

Farid J. Azzam MD, Andrew C. Fiore $M D$, ${ }^{*}$

Purpose: To report the management of junctional ectopic tachycardia after cardiac surgery in an infant. Postoperatively, the patient suffered profound cardiac decompensation secondary to the accelerated rhythm and required extracorporeal membrane oxygenation (ECMO) for haemodynamic support.

Clinical features: A 14-day-old, $3.5 \mathrm{~kg}$ boy exhibited junctional ectopic tachycardia after cardiopulmonary bypass. Left atrial pressure was $25-28 \mathrm{mmHg}$. No impact on the tachycardia was seen after rapid overdrive atrial pacing or after $20 \mu \mathrm{g}$ fentanyl iv, $45 \mu \mathrm{g}$ digitalis, $100 \mathrm{mg}$ magnesium or procainamide (loading dose $15 \mathrm{mg}$, then $\left.30 \mathrm{mg} \cdot \mathrm{kg}^{-1} \cdot \mathrm{min}^{-1}\right)$. Active cooling decreased the nasopharyngeal temperature to $35.2^{\circ} \mathrm{C}$, when the heart rate decreased below $180 \mathrm{bpm}$ with a left atrial pressure of $8-10 \mathrm{mmHg}$. Dopamine $\left(2 \mu \mathrm{g} \cdot \mathrm{kg}^{-1} \cdot \mathrm{min}^{-1}\right)$ and dobutamine $\left(5 \mu \mathrm{g} \cdot \mathrm{kg}^{-1} \cdot \mathrm{min}^{-1}\right)$ were added to improve the cardiac output. Sodium nitroprusside $\left(0.25\right.$ to $\left.1 \mu \mathrm{g} \cdot \mathrm{kg}^{-1} \cdot \mathrm{min}\right)$ maintained the systolic pressure $<100 \mathrm{mmHg}$. On arrival in ICU, heart rate increased to $200 \mathrm{bpm}$. The patient received cardiac massage for severe hypotension 75 min after surgery. Emergency ECMO was instituted for circulatory support. Procainamide, digoxin, dopamine, dobutamine, sodium nitroprusside and hypothermia were continued. Sinus rhythm resumed on the first postoperative day, but procainamide and induced hypothermia at $34^{\circ} \mathrm{C}$ were maintained for $36 \mathrm{hr}$ after normalization of the rhythm to prevent recurrence of the tachycardia. Total duration of ECMO was three and a half days. Recovery was uneventful.

Conclusion: The use of ECMO, as a first line of defence, is suitable for the emergency support of patients with JET because of the ease of support of circulation and precise control of hypothermia.

Objectif : Décrire le traitement d'une tachycardie ectopique jonctionnelle (TEJ) survenue chez un enfant, après une chirurgie cardiaque, alors qu'il a souffert d'une profonde décompensation cardiaque secondaire au rythme accéléré et a eu besoin d'oxygénation extracorporelle (OEC) pour un soutien hémodynamique.

Aspects cliniques : Un garçon de 14 jours, pesant $3,5 \mathrm{~kg}$, a présenté une tachycardie ectopique jonctionnelle à la suite d'une circulation extracorporelle. La pression auriculaire gauche était de $25-28 \mathrm{mmHg}$. II n'y a pas eu d'impact sur la tachycardie à la suite de l'entraînement électrosystolique auriculaire rapide ou l'administration de $20 \mu \mathrm{g}$ de fentanyl iv, $45 \mu \mathrm{g}$ de digitale, $100 \mathrm{mg}$ de magnésium ou de procaïnamide (dose d'attaque de $15 \mathrm{mg}$, suivie de $30 \mathrm{mg} \cdot \mathrm{kg}^{-1} \cdot \mathrm{min}^{-1}$ ). Le refroidissement actif a diminué la température nasopharyngienne à $35,2^{\circ} \mathrm{C}$, tandis que la fréquence cardiaque a diminué sous $180 \mathrm{bpm}$ avec une pression auriculaire gauche de $8-10 \mathrm{mmHg}$. La dopamine $\left(2 \mu \mathrm{g} \cdot \mathrm{kg}^{-1} \cdot \mathrm{min}^{-1}\right)$ et la dobutamine $\left(5 \mu \mathrm{g} \cdot \mathrm{kg}^{-1} \cdot \mathrm{min}^{-1}\right)$ ont amélioré le débit cardiaque. Le nitroprussiate de sodium $\left(0,25 \mathrm{a} \mid \mu \mathrm{g} \cdot \mathrm{kg}^{-1} \cdot \mathrm{min}\right)$ a maintenu la pression systolique $<100 \mathrm{mmHg}$. À l'arrivée à l'USI, la fréquence cardiaque a augmenté à $200 \mathrm{bpm}$. Le patient a reçu un massage cardiaque pour une hypotension sévère, 75 min après la chirurgie. L'OEC d'urgence a été mise en place pour assurer la circulation. On a poursuivi l'administration de procainamide, de digoxine, de dopamine, de dobutamine, de nitroprussiate de sodium et on a maintenu I'hypothermie. Le rythme sinusal s'est rétabli le jour suivant l'intervention, mais on a maintenu la procainamide et I'hypothermie provoquée à $34^{\circ} \mathrm{C}$ pendant $36 \mathrm{~h}$ après le retour du rythme normal afin de prévenir une tachycardie récurrente. La durée totale de l'OEC a été de trois jours et demi. La récupération s'est déroulée sans incident.

Conclusion : L'utilisation de l'OEC, comme défense de première ligne, est appropriée au soutien d'urgence de patients qui présentent une TEJ parce qu'elle entretient aisément la circulation et le contrôle précis de l'hypothermie.

From the Departments of Anesthesiology and Surgery, ${ }^{*}$ Saint Louis University Medical Center, 3635 Vista Avenue, St. Louis, MO 63110. Address correspondence to: Farid J. Azzam MD, Department of Anesthesiology; Phone: 314-577-5622; Fax: 314- 268-4099 Accepted for publication $25 \mathrm{Jull} 1998$. 
$\mathrm{P}$ OSTOPERATIVE junctional ectopic tachycardia (JET) is a life-threatening arrhythmia with highest incidence in neonates and infants undergoing complex cardiac surgical repairs. ${ }^{1}$ Although JET is of special interest to the anaesthetist because of its possible occurrence in the immediate post-repair period, its anaesthetic implications and its unusual mode of treatment, it has not been described in the anaesthesia literature. We report a case where JET was treated with extracorporeal membrane oxygenation (ECMO) support.

\section{Case report}

A 14-day-old, $3.5 \mathrm{~kg}$ patient with D-transposition of great vessels, patent ductus arteriosus and bidirectional atrial shunting presented for an arterial switch procedure, using hypothermic cardiopulmonary bypass (CPB). Anaesthesia was induced with inhalation of sevoflurane (3 - 5\%) and maintenance consisted of intermittent fentanyl (total dose $120 \mu \mathrm{g}$ and isoflurane $(0.5-0.75 \%)$, with vecuronium for neuromuscular blockade (initial dose of $0.1 \mathrm{mg} / \mathrm{kg}$, followed by intermittent doses; total dose $=2.7 \mathrm{mg}$ ). Monitoring included an electrocardiogram, pulse oximetry, mass spectrometry, temperature, arterial and central venous pressure. Midazolam $1 \mathrm{mg}$ iv was given before CPB. Isoflurane $0.5 \%$ was administered through the $\mathrm{CPB}$ pump. After discontinuation of $\mathrm{CPB}$, the patient exhibited a regular tachycardia at 200 beats $\mathrm{min}^{-1}$ (bpm) with narrow QRS. Most QRS complexes were not associated with a visible $P$ wave, but, intermittently, a P-QRS complex was seen, indicating $\mathrm{AV}$ association. Systolic blood pressure was $80-100 \mathrm{mmHg}$ and right atrial pressure was 6-8 mmHg. The left atrial pressure was 25-28 $\mathrm{mmHg}$, but decreased to 8-10 during periods of $\mathrm{AV}$ synchrony or when the heart rate decreased below 180 bpm. Potassium was $3.7 \mathrm{mEq} / \mathrm{L}$ and magnesium was $1.6 \mathrm{mg} / \mathrm{dl}$. Arterial blood gas analysis revealed $\mathrm{pH}$ $7.53, \mathrm{PCO}_{2} 31 \mathrm{mmHg}, \mathrm{PaO}_{2} 295 \mathrm{mmHg}$, base excess 4.1 $\left(\mathrm{FIO}_{2}=1.0\right)$. Mixed venous saturation measured by an oximetrix@ right atrial catheter was $70-73 \%$. Administration of $i v$ fentanyl $20 \mu \mathrm{g}$ had no effect on the tachycardia. Rapid overdrive atrial pacing was effective in capturing the atria, but did not result in resolution of the tachycardia after termination of pacing. The diagnosis of junctional ectopic tachycardia was made and ip digitalis $45 \mu \mathrm{g}$, magnesium $100 \mathrm{mg}$ and procainamide (15 mg loading dose over $20 \mathrm{~min}$, followed by an infusion at $30 \mu \mathrm{g} \cdot \mathrm{kg}^{-1} \cdot \mathrm{min}^{-1}$ ) were administered. Active cooling was initiated, first by the circulating water mattress, then by convecting atmospheric air at room temperature over the patient's head and arms using a Bair Hugger (Augustine Medical, Inc, Eden Prairie, MN). The patient's nasopharyngeal temperature decreased slowly from a postbypass of $37.8^{\circ} \mathrm{C}$ to $35.2^{\circ} \mathrm{C}$. The heart rate decreased below $180 \mathrm{bpm}$ with a corresponding left atrial pressure of $8-10 \mathrm{mmHg}$. Dopamine $\left(2 \mu \mathrm{g} \cdot \mathrm{kg}^{-1} \cdot \mathrm{min}^{-1}\right)$ and dobutamine $\left(5 \mu \mathrm{g} \cdot \mathrm{kg}^{-1} \cdot \mathrm{min}^{-1}\right)$ were added to improve the cardiac output. Sodium nitroprusside ( 0.25 to $1 \mu \mathrm{g} \cdot \mathrm{kg}^{-1} \cdot \mathrm{min}$ ) was necessary to maintain the systolic pressure below $100 \mathrm{mmHg}$.

In the intensive care unit, the HR was $180 \mathrm{bpm}$ and the blood pressure $92 / 55 \mathrm{mmHg}$. Rectal temperature was $33.8^{\circ} \mathrm{C}$. Shortly after arrival however, the heart rate increased to a mean of $200 \mathrm{bpm}$. Seventy-five minutes after the end of surgery, the patient developed severe hypotension with a systolic pressure of $30-40 \mathrm{mmHg}$ and required cardiac massage. Emergency ECMO was instituted for circulatory support. Procainamide, digoxin, dopamine, dobutamine sodium nitroprusside and hypothermia were continued. An echocardiogram obtained nine hours after institution of ECMO showed a shortening fraction of $33 \%$, indicating good left ventricular function. An atrial electrogram obtained using the pacing wire implanted at the time of surgery demonstrated atrio-ventricular (AV) dissociation with a ventricular rate of $160 \mathrm{bpm}$ (Figure 1). Sinus rhythm resumed on the first postoperative day, but procainamide drip and induced hypothermia at $34^{\circ} \mathrm{C}$ (rectal temperature) were maintained for $36 \mathrm{hr}$ after normalization of rhythm to prevent recurrence of the tachycardia. Total duration of ECMO was three and a half days. Recovery was uneventful and the patient was discharged in good condition on the 15 th postoperative day.

\section{Discussion}

Our patient exhibited a regular tachycardia at $200 \mathrm{bpm}$ after termination of cardiopulmonary bypass after an arterial switch procedure. The differential diagnosis included sinus tachycardia, primary atrial tachycardia, atrioventricular reentry tachycardias and junctional ectopic tachycardia. ${ }^{1}$ Junctional ectopic tachycardia was the most probable diagnosis in view of the presentation of a narrow-QRS tachycardia, no visible $\mathrm{P}$ waves, $\mathrm{AV}$ dissociation and intermittent $\mathrm{AV}$ association. The atrial electrogram obtained at a later time documented the AV dissociation with the atrial rate being slower than the ventricular rate (Figure 1).

Junctional ectopic tachycardia is due to an abnormal automaticity of the AV node with AV dissociation. The morphology of the QRS is similar to that in sinus rhythm, although a wide QRS may be seen if there is an associated bundle branch block. The ventricular rate is commonly between 180 and $250 \mathrm{bpm}$. The atrial rate is usually slower at around $140 \mathrm{bpm}$, but the $P$ waves are difficult to identify as they wander through the QRS. ${ }^{1}$ One-to-one retrograde conduction may result in $\mathrm{AV}$ association. 


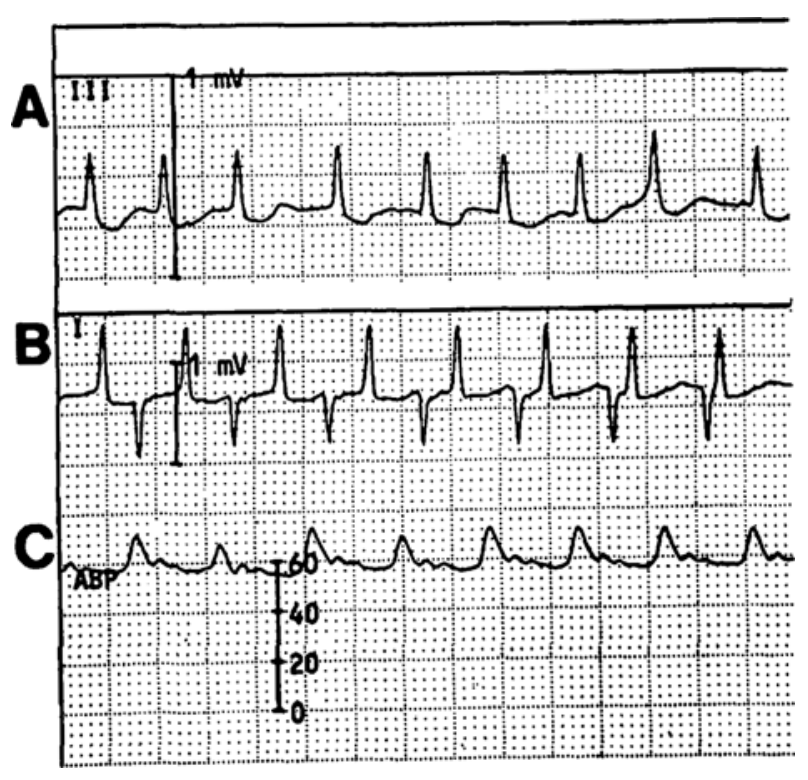

FIGURE 1 Tracings obtained on ECMO nine hrs postoperatively. A: Lead II ECG. B: Atrial electrogram. C: Arterial pressure.

Two forms of JET, congenital and acquired (postoperative), are recognized. Congenital JET manifests early in infancy and carries a high mortality rate. Postoperative JET, occurring either immediately after repair or within the first 72 hours, is associated most frequently with correction of tetralogy of Fallot, atrial partition procedures for transposition of the great vessels, closure of ventricular septal defect and other complex congenital cardiac repairs. ${ }^{1}$ Manipulation of the right atrium and ventricle in the vicinity of the bundle of His seems to be a factor in the development of JET. ${ }^{2}$ Till and Rowland ${ }^{2}$ found at autopsy in three patients who died after postoperative JET that there were haemorrhagic tracks invading the AV bundle. These tracks originated from stitches placed close to the conduction system.

Increased adrenergic tone contributes to the aggravation of postoperative JET. The tachycardia and the loss of "atrial kick" secondary to AV dissociation cause poor ventricular filling and low cardiac output. ${ }^{3}$ This in turn results in a reactive increase of adrenergic activity which perpetuates the vicious cycle by further increasing the heart rate. Thus JET has been described as "feeding upon itself". 3 This cycle of events may compound the deleterious effects of surgery and cardiopulmonary bypass on cardiac function and lead to significant mortality in the absence of palliation. ${ }^{3}$

Treatment of postoperative JET is challenging. The general goals are to decrease adrenergic tone, maxi- mize cardiac output, increase vagal tone, normalize serum electrolytes and induce hypothermia. ${ }^{3,4}$ Sympathomimetics and digitalis may be used as needed to maximize cardiac output. Any drug with vagolytic effect, such as pancuronium and meperidine, must be avoided. ${ }^{3}$ Similarly, hypotensive agents, such as sodium nitroprusside, and drugs causing histamine release, such as atracurium, should be avoided or used with extreme caution, because the resulting hypotension may induce a reactive increase in tachycardia. Potassium, calcium and magnesium levels need to be optimized to high normal values. ${ }^{3}$

The armamentarium of antiarrhythmics used to treat JET is limited and includes procainamide, digitalis, amiodarone and propafenone. Procainamide is frequently used but some believe it is ineffective and may have an adverse effect on myocardial contractility and vagal tone. ${ }^{3}$ Although digitalis decreases the heart rate only by a few beats, probably through a vagal effect, ${ }^{5}$ it is valuable to maximize the cardiac output without increasing the adrenergic tone. Amiodarone, a class III $\mathrm{drug}$, induces a prolongation of the action potential of atrial, nodal and ventricular myocardial cells. It increases the repolarization and refractory periods and has non-competitive alpha and beta adrenergic effects. ${ }^{6}$ Amiodarone, by itself or in association with hypothermia, has been used successfully in the treatment of JET. ${ }^{7-8}$ Propafenone is a class Ic antiarrhythmic agent with local anaesthetic and beta-adrenergic blocking properties. Propafenone has also been reported to be useful in the setting of postoperative JET ${ }^{9}$ but it is not available in an intravenous form in all countries. Both amiodarone and propafenone have proarrhythmic effects (primarily torsades de pointe) and caution should be exercised in their use in pediatric patients. ${ }^{7,10}$ Of interest is that verapamil can induce preexcited atrial fibrillation and should be avoided. ${ }^{11}$

Induced hypothermia to a temperature of 32 $35^{\circ} \mathrm{C}$ reduces the rate of automatic depolarization of all cardiac cells and, although it does not convert JET, it lowers the heart rate to around $160 \mathrm{bpm} .4,12,13$ This promotes better diastolic filling and higher cardiac output and permits AV sequential pacing. Shivering must be prevented, usually through muscle paralysis. Rewarming is initiated after the patient's heart rate has been stable for 24 hours. Pfammatter et al. reported on six infants with postoperative JET who were treated with hypothermia while under sedation, paralysis and mechanical ventilation. ${ }^{13}$ Lowering the rectal temperature to $32-34^{\circ} \mathrm{C}$ was successful in decreasing the tachycardia from $219 \pm 27 \mathrm{bpm}$ to $165 \pm 25 \mathrm{bpm}$ within four hours. Cooling was maintained for a period of 24 to $88 \mathrm{hr}$, without severe metabolic acidosis or 
electrolyte imbalance. Predominant sinus rhythm resumed after 5.5 days (range 3 to 10 days).

Keeping with these recommendations, magnesium was administered to our patient, along with a loading dose of digitalis. Low dose dopamine and dobutamine were started in an effort to improve the cardiac output. As expected, overdrive pacing was not successful in terminating the arrhythmia. ${ }^{1}$ Hypothermia was instituted in the operating room but the elapsed time before the cardiac decompensation might have been insufficient to allow for the reduction of the rate of firing of the AV node. In conjunction with ECMO and procainamide, hypothermia at $34^{\circ} \mathrm{C}$ was effective in lowering the heart rate to $160 \mathrm{bpm}$ within eight hours. The use of amiodarone was planned in case the above regimen was not successful.

In spite of what seemed to be adequate treatment, the patient sustained a cardiovascular collapse necessitating ECMO for support of the circulation. We believe that this circulatory collapse was caused by the rhythm disturbance, not by intrinsic myocardial dysfunction secondary to cardiotomy or cardiopulmonary bypass. The cardiac output in the operating room was adequate, as reflected by the high mixed venous oxygen saturation. The echocardiogram performed 9 hours after the patient was placed on ECMO showed excellent myocardial function. The elevated left atrial pressure may have been related to the lack of myocardial relaxation and poor ventricular and atrial compliance induced by the high heart rate. In addition, in AV dissociation, forceful atrial contractions during ventricular systole and against a closed mitral valve produce socalled "cannon waves" that increase the atrial pressure. Effectively, the left atrial pressure decreased to 8-10 $\mathrm{mmHg}$ when the heart rate decreased below $180 \mathrm{bpm}$ or when there was $\mathrm{AV}$ association.

Junctional ectopic tachycardia is a life-threatening arrhythmia. In emergency situations, extraordinary measures may be needed. Braunstein et al. reported on an infant who developed postoperative JET unresponsive to medical treatment and who underwent emergency cryoablation of the His bundle with a subsequent permanent pacemaker. ${ }^{14}$ Newer techniques of radiofrequency ablation may be more successful in preserving $\mathrm{AV}$ conduction..$^{15}$ However, as JET is a transient arrhythmia usually resolving within 72 hours, ECMO support is a viable alternative to ablation in life-threatening situations. ECMO is an established effective modality for circulatory support in patients with post-cardiac surgery heart failure. ${ }^{16}$ Although the risks of infection, bleeding and neurological damage ${ }^{16}$ preclude the use of ECMO as a first line of defense, ECMO is highly suitable for emergency support of patients with JET because of the ease of support of the circulation and precise control of the hypothermia.

\section{References}

I Case CL, Gillette PC. Automatic atrial and junctional tachycardias in the pediatric patient: strategies for diagnosis and management. Pacing Clin Electrophysiol 1993; 16: 1323-35.

2 Till JA, Ho SY, Rowland E. Histopathological findings in three children with His bundle tachycardia occurring subsequent to cardiac surgery. Eur Heart J 1992; 13: 709-12.

3 Gillette PC. Diagnosis and management of postoperative junctional ectopic tachycardia. Am Heart J 1989; 118: 192-4.

4 Bash SE, Shah J, Albers WH, Geiss DM. Hypothermia for the treatment of postsurgical greatly accelerated junctional ectopic tachycardia. J Am Coll Cardiol 1987; 10: 1095-9.

5 Grant JW, Serwer GA, Armstrong BE, Oldham HN, Anderson $P A W$. Junctional tachycardia in infants and children after open heart surgery for congenital heart disease. Am J Cardiol 1987; 59: 1216-8.

6 Gill J, Heel RC, Fitton A. Amiodarone. An overview of its pharmacological properties and review of its therapeutic use in cardiac arrhythmias. Drugs 1992; 43: 69-110.

7 Raja P, Hawker RE, Chaikitpinyo $A$, et al. Amiodarone management of junctional ectopic tachycardia after cardiac surgery in children. Br Heart J 1994; 72: 261-5.

8 Perry JC, Fenrich AL, Hulse JE, Triedman JK, Friedman RA, Lamberti JJ. Pediatric use of intravenous amiodarone: efficacy and safety in critically ill patients from a multicenter protocol. J Am Coll Cardiol 1996; 27: 1246-50.

9 Garson A Jr, Moak JP, Smith RT Jr, Norton JB Jr. Usefulness of intravenous propafenone for control of postoperative junctional ectopic tachycardia. Am J Cardiol 1987; 59: 1422-4.

10 Hobnloser SH, Klingenheben $T$, Singh BN. Amiodaroneassociated proarrhythmic effects. A review with special reference to torsade de pointes tachycardia. Ann Intern Med 1994; 121: 529-35.

11 Garratt $C$, Ward $D$, Camm AJ. Degeneration of junctional tachycardia to pre-excited atrial fibrillation after intravenous verapamil (Letter). Lancet July 22, 1989: 219.

12 Balagi S, Sullivan I, Deanfield J, James I. Moderate hypothermia in the management of resistant automatic tachycardias in children. Br Heart J 1991; 66: 221-4.

13 Pfammatter J-P, Paul T, Ziemer G, Kallfelz HC. Successful management of junctional tachycardia by hypothermia after cardiac operations in infants. Ann Thorac Surg 1995; 60: 556-60. 
14 Braunstein PW Jr, Sade RM, Gillette PC. Life-threatening postoperative junctional ectopic tachycardia. Ann Thorac Surg 1992; 53: 726-8.

15 Toung $M-L$, Mebta $M B$, Martinez RM, Wolff $G S$, Gelband $H$. Combined alpha-adrenergic blockade and radiofrequency ablation to treat junctional ectopic tachycardia successfully without atrioventricular block. Am J Cardiology 1993; 71: 883-5.

16 Raithel SC, Pennington DG, Boegner E, Fiore A, Weber TR. Extracorporeal membrane oxygenation in children after cardiac surgery. Circulation 1992; 86 (Suppl): II305-10. 